\title{
Ready-to-Eat Cereal Consumption Patterns: The Relationship to Nutrient Intake, Whole Grain Intake, and Body Mass Index in an Older American Population
}

\author{
Ann M. Albertson, ${ }^{1}$ A. Christine Wold, ${ }^{2}$ and Nandan Joshi ${ }^{3}$ \\ ${ }^{1}$ General Mills: Bell Institute of Health and Nutrition, James Ford Bell Technical Center, 9000 Plymouth Avenue North, \\ Minneapolis, MN 55427, USA \\ ${ }^{2}$ General Mills: Quality \& Regulatory Operations, 1 General Mills Boulevand, BT 10-D-1, Minneapolis, MN 55426, USA \\ ${ }^{3}$ General Mills India Pvt. Ltd., 601-Prudential, Hiranandani Business Park, Powai, Mumbai 400076, India
}

Correspondence should be addressed to Ann M. Albertson, ann.albertson@genmills.com

Received 13 April 2012; Revised 21 July 2012; Accepted 3 September 2012

Academic Editor: Nadine Sahyoun

Copyright (c) 2012 Ann M. Albertson et al. This is an open access article distributed under the Creative Commons Attribution License, which permits unrestricted use, distribution, and reproduction in any medium, provided the original work is properly cited.

\begin{abstract}
Objective. To investigate the relationship between ready-to-eat (RTE) breakfast cereal consumption patterns and body mass index (BMI), nutrient intake, and whole grain intake in an older American population. Design. A cross-sectional survey of US households, collected by the NPD Group via the National Eating Trends (NET) survey. Main outcome measures include BMI, nutrient intake, and whole grain intake. Subjects/Setting. The sample included 1759 participants age 55 and older, which was divided into approximate quartiles based on intake of RTE breakfast cereal for the 2-week period ( 0 servings, $1-3$ servings, 4-7 servings, and $\geq 8$ servings). Results. In the multivariate linear regression analysis adjusted for energy and age; intake of dietary fiber, whole grains, and the majority of micronutrients examined were found to be positively associated with frequent RTE cereal consumption. The proportion of participants consuming less than the Estimated Average Requirement (EAR) was lower for the highest quartile of RTE cereal consumers compared to nonconsumers, for the majority of vitamins and minerals examined. Significant differences in BMI between RTE breakfast cereal intake groups were found for men. Conclusion. Results suggest that ready-to-eat breakfast cereals may contribute to the nutritional quality of the diets of older Americans. Prospective studies and experimental trials are needed to better evaluate the role of RTE cereal consumption in energy balance.
\end{abstract}

\section{Introduction}

According to US Department of Health and Human Services, Administration on Aging population estimates, the number of older Americans is expected to grow dramatically. By 2030, the number of adults aged $60+$ is expected to increase to approximately $25 \%$ of the population, while the number of the oldest old (age 85+) is expected to double [1]. Adequate nutrition is an important factor in continued health and independence for older adults $[2,3]$.

Homebound elderly people who skip breakfast are more likely to have inadequate nutrient intakes [2]. Caloric needs typically drop with advancing age, while needs for certain micronutrients such as calcium, vitamin $\mathrm{D}$, and vitamin $\mathrm{B}_{12}$ increase [4]. Thus the importance of choosing nutrient dense foods increases for this population. Several cross-sectional studies have found positive associations between breakfast consumption and RTE breakfast cereal consumption, and increased nutrient intake for adult and elderly adult populations [5-8]. RTE cereal provides a convenient and easy to prepare breakfast option, which can provide whole grains and dietary fiber, along with many vitamins and minerals. RTE breakfast cereal is also an important contributor of whole grain in the US diet, providing approximately $30 \%$ of daily whole grain intake [9]. Recently, whole grain intake was found to be inversely associated with BMI and abdominal body fat in an older American population [10].

Similar to other age groups, the prevalence of overweight and obesity in the elderly population is increasing [11]. An estimated $76.5 \%$ of men and $73.5 \%$ of women $\geq 60$ years old 
are currently overweight or obese (BMI $\geq 25)$ while $36.6 \%$ of men and $42.3 \%$ of women $\geq 60$ years old are estimated to be obese $(\mathrm{BMI} \geq 30)[12]$. Based on recent NHANES data, McKeown estimates $62.5 \%$ of men and $74.9 \%$ of women ages 60 to 69 years old are abdominally obese [10]. It has been suggested that abdominal obesity may be a better measure of obesity than BMI in an older population, since after the age of 60 this population tends to lose lean body mass, while increasing visceral body fat [13].

A number of cross-sectional studies have examined the association of ready-to-eat (RTE) cereal intake with nutrient intake and body weight status. RTE cereal consumption has been found to be positively associated with intake of a range of vitamins and minerals and inversely associated with body mass index (BMI) in child and adolescent populations $[14,15]$. In addition, eating breakfast along with a pattern of frequent ready-to-eat cereal consumption is associated with lower BMI, higher nutrient intakes, and weight maintenance in adults [7, 16-19]. Research in older adults is lacking. Thus, we examined the association of RTE cereal consumption patterns with nutrient intake in a sample of older adults who participated in a cross-sectional survey. The association of RTE cereal consumption with BMI and percent overweight or obese $(\mathrm{BMI} \geq 25)$ was also examined in this study.

\section{Methods}

Data collected as part of the National Eating Trends (NET) survey were analyzed. The NET survey is conducted by the NPD Group, a marketing information company that has been monitoring the intake of US households since 1980 through this survey [20]. As described previously, the General Mills Bell Institute of Health and Nutrition (BIHN) has developed a proprietary method for combining data from the NET survey's 14-day food diary data, with portion size estimates from the National Health and Nutrition Examination Survey (NHANES) 1999-2004, and nutrient and food group data from the University of Minnesota's Nutrient Data System for Research (NDSR) Version 34, 2008 (Nutrition Coordinating Center, Minneapolis, MN) [14]. This combined dataset allows for population based, food pattern comparisons of usual intake, based on categories of foods consumed.

2.1. Food Consumption Data. Annually, the NET survey samples 2,000 households representing approximately 10,000 individuals, and data from the March 2006 through February 2008 survey were used for this study. To be included in this study, the subjects must have completed at least 7 days of food reporting and have provided height and weight data for calculation of BMI. The NET survey included 1905 participants age 55 and older, of these 1759 completed at least 7 days of food diaries and provided height and weight data (92\%). Of these 1759 participants, $46 \%$ were male, 54\% were female, and $22 \%$ were $\geq 75$ years old.

For the NET survey, each year the NPD Group collaborates with a third party to establish a mail access panel that is a cross-sectional group of US households (noninstitutionalized people in the contiguous 48 states). Survey targets are set for the following demographic factors (family versus nonfamily, age, household income, household size, age of head of household, employment status, race, and census region) based on US Census Bureau statistics. NPD uses historical response data to over-sample households with lower expected response rates and adjusts the target levels quarterly to obtain a demographically and geographically balanced sample. Panelists are recruited using mailing lists and mall interventions, and NET survey panelists are then randomly selected from active mail panelists (those who have returned at least 1 other survey). Participant incentives include selection from a range of gifts ( $\$ 25$ to $\$ 30$ value). Approximately $72 \%$ of households provide completed surveys for at least 10 of the 14 days of the annual survey.

Recruitment and data collection were conducted across all 52 weeks of the year. Each household member was required to document food and beverage intake by maintaining a daily eating diary. The "person most responsible for meal preparation" was responsible for documenting the name and brand of all food consumed for all household members, including any additions with cooking or food preparation. Description of the meal occasion (breakfast, lunch, snack, etc.) and location (at home, away from home) was included in the diary along with food names, flavor descriptors, brand names, package types, product form, special nutritional attributes, and other details. Food diary records were mailed back on a daily basis for the 14 day period.

2.2. Food Diary Data Entry. The University of Minnesota's Nutrition Database System for Research (NDS-R) provided the nutrient and food group data for this study. The NDS$\mathrm{R}$ system provides a comprehensive database of complete nutrient data for 156 nutrients or components, for over 18,000 foods. The database is updated on an ongoing basis and contains over 7,000 brand name products. NDS-R has over 100 food groups in the database and each food is assigned a food group. Completed food diaries were entered into NDS-R for calculation of nutrient intake and food groups. Foods reported by NET survey panelists were matched, based on food diary descriptions to foods included in the NDS-R database. The recipe module of the NDS software was used to assign nutrient values to foods with special attributes (low fat, calcium fortified, reduced sodium, etc.) which were not found in the database and each recipe was assigned an appropriate food group.

2.3. Portion-Size Data. NET panelists record the foods and beverages consumed by household members but not the quantities. This procedure is standard for panel surveys to minimize recorder burden and thus increase reliability. Portion-sizes were estimated by combining data from the NHANES 1999-2004. Serving weights for individual food codes were aggregated and then collapsed for like-foods to strengthen cell sizes, and smoothed to eliminate outliers. Age and gender-specific mean serving weights were thereby determined for over 800 food types; these portions were subsequently assigned to each food recorded and coded in the NET diary. 
2.4. Data Tabulation. Of the 1905 older American adults who were included in the NET survey, 146 participants were excluded for not meeting the inclusion criteria. $94 \%$ of those in the analytic sample provided complete (14 days) food diaries. For the $6 \%$ of participants with 7 to 13 days of dietary information the estimated servings of RTE cereal were normalized to 14 to allow for placement in the study quartiles. The pattern established over the 7- to 13-day period was assumed to be constant for the full 14 days. For example if no RTE cereal was consumed in the days collected, no servings would be included for the full 14 days, or if 2 servings were consumed in 7 days, 4 servings would be assumed for the full 14-day period. Self-reported values for height and weight were provided by each individual in the study. BMI was calculated by using the formula: $\mathrm{BMI}=$ weight $(\mathrm{lb}) /$ height $(\text { in })^{2} \times 703$.

Servings of whole grains consumed by study participants were estimated based on food group assignments in the NDS-R database. All grain-based foods in the NDSR database are categorized as being either "whole grain," "some whole grain" or "refined grain". To be assigned to the "whole grain" category the first grain ingredient in the product must be a whole grain. Foods assigned to the "some whole grain" category are products that contain whole grain ingredients, but the first grain ingredient is not a whole grain. "Refined grain" products are those that contain no whole grain ingredients. In this paper servings of whole grains were calculated by summing serving of foods classified as "whole grain" in the database.

2.5. Statistical Analysis. To examine whether RTE cereal consumption was associated with BMI, body weight status, whole grain, and nutrient intake a series of analysis of variance (ANOVA) models were conducted by approximate quartiles of RTE cereal intake. Slightly greater than one quarter of the participants were nonconsumers, which made breaks in intake levels approximate rather than exact quartiles of RTE cereal intake (Table 1).

Logistic regression modeling was conducted to examine the association between RTE cereal consumption pattern and odds of falling below Estimated Average Requirement (EAR) for micronutrients with an established intake level. Covariates included within the ANOVA and logistic regression models were energy and age. Values were adjusted for energy to see if RTE cereal consumption was associated with a more nutrient dense diet. Age was included as a covariate, because it is associated with both RTE cereal consumption and nutrient intake. The contrasts were examined between the possible pairs of cereal consumption categories using the Wald chi-square test.

Logistic regression was used to compare odds of being overweight or obese by level of RTE cereal consumption. The contrasts were examined between the possible pairs of cereal consumption categories using the Wald chi-square test. For both the ANOVA and logistic regression models examining the association of RTE cereal consumption with body weight age and age ${ }^{2}$ were included as covariates. Age $^{2}$ was included because the relationship between BMI and age is not linear, around 60 years of age this relationship can change [13]. All analyses were stratified by sex, because it was hypothesized that the association of RTE cereal consumption with the measured outcomes may vary by sex.

An alpha level of 0.01 was used to determine the significance for the analysis of variance comparisons, except where otherwise noted. All analyses were performed using SAS version 9.2 (SAS Institute, Cary, NC).

\section{Results}

The sample size and RTE cereal consumption distribution are displayed in Table 1. With respect to findings related to food and nutrient intake, the objective of this study was to determine the relationship between RTE cereal quartile of consumption to nutrient intake. For both men and women in the sample, significant differences in nutrient intakes between the fourth quartile (Q4) compared to the lowest two quartiles (Q1 and Q2) of RTE cereal consumption were seen for most nutrients examined (Table 2). For males, Q4 intake of energy was higher compared to Q1 and Q2. After adjusting for energy and age there was a significantly lower $(P<0.01)$ intake of total fat, total saturated fat, total trans fat, and cholesterol among those in Q4 compared to Q1 and Q2. In addition among men, intakes of total carbohydrate, dietary fiber, total sugar, vitamin A, vitamin $C$, vitamin $\mathrm{D}$, thiamin, riboflavin, niacin, vitamin $\mathrm{B} 6$, folate, vitamin B12, potassium, calcium, iron, magnesium, and zinc were significantly higher $(P<0.01)$ among those in Q4 compared to those in Q1 and Q2. There were no significant differences between intake of total protein, added sugar, or vitamin E across consumption patterns of RTE cereal. Sodium intake was not significantly different between the highest and lowest quartiles of intake. Similar relationships were found for women age $55+$ (Table 3 ), with the exception of total sugar intake which was not significantly different across quartiles of RTE cereal intake.

In addition to significant differences in nutrient intake, this study found whole grain intake to be positively associated with RTE cereal consumption. For both men and women, average whole grain intake among those in Q4 of RTE cereal consumption was nearly double the whole grain intake of those in the Q1 (the nonconsumers) (Tables 2 and 3).

The percentage of participants in each quartile that fell below Estimated Average Requirement (EAR) for nutrients with established EAR amounts was examined (Table 4). A significant inverse linear relationship was found between the frequency of RTE cereal consumption and the percentage of participants failing to consume the EAR for a number of nutrients. In women, this relationship was found for all nutrients examined except vitamin D and $\mathrm{E}$ and for men, all but niacin and iron.

In examining the relationship of RTE cereal consumption patterns and BMI there were some significant differences found in mean BMI for all men and all women (Table 5). With respect to men, the adjusted mean BMI was significantly lower among those in Q4 compared to Q1 and Q2 $(P=0.0332)$. For women, there were significant differences between Q3 and Q4, but no significant differences between the highest and lowest quartiles of RTE cereal intake. 
TABLE 1: Sample size and RTE cereal consumption distribution for adults 55+ from the 2007-2008 NET survey.

\begin{tabular}{|c|c|c|c|c|c|}
\hline \multirow{3}{*}{ Gender/age } & \multirow{3}{*}{ Sample size } & \multicolumn{4}{|c|}{ Quartile of cereal consumption } \\
\hline & & Q1 & Q2 & Q3 & Q4 \\
\hline & & $\begin{array}{c}0 \\
\text { Servings/14 d } \\
n(\%) \\
\end{array}$ & $\begin{array}{c}1-3 \\
\text { Servings/14d } \\
n(\%) \\
\end{array}$ & $\begin{array}{c}4-7 \\
\text { Servings/14 d } \\
n(\%) \\
\end{array}$ & $\begin{array}{c}8+ \\
\text { Servings/14 d } \\
n(\%) \\
\end{array}$ \\
\hline All adults ages 55+ & 1759 & $490(27.9)$ & $484(27.5)$ & $380(21.6)$ & $405(23.0)$ \\
\hline Males ages 55+ & 803 & $231(28.8)$ & $207(25.8)$ & $165(20.6)$ & $200(24.9)$ \\
\hline Females ages 55+ & 956 & $259(27.1)$ & $277(29.0)$ & $215(22.5)$ & $205(21.4)$ \\
\hline
\end{tabular}

TABLE 2: Adjusted* mean daily nutrient intake for adult men, ages 55+, by quartile of cereal consumption.

\begin{tabular}{|c|c|c|c|c|c|}
\hline \multirow{4}{*}{ Nutrient } & \multicolumn{4}{|c|}{ Quartile of RTE cereal consumption } & \multirow{4}{*}{$P$} \\
\hline & Q1 & Q2 & Q3 & Q4 & \\
\hline & 0 Servings & 1-3 Servings & 4-7 Servings & $8+$ Servings & \\
\hline & Mean \pm SE & Mean \pm SE & Mean \pm SE & Mean \pm SE & \\
\hline Energy (kcal) & $1826 \pm 38^{\mathrm{a}}$ & $1932 \pm 39^{\mathrm{ab}}$ & $2033 \pm 45^{\mathrm{bc}}$ & $2142 \pm 43^{\mathrm{c}}$ & $<0.0001$ \\
\hline Total fat (g) & $81 \pm 1.6^{\mathrm{a}}$ & $80 \pm 1.8^{\mathrm{a}}$ & $76 \pm 2.0^{\mathrm{b}}$ & $73 \pm 1.9^{c}$ & $<0.0001$ \\
\hline Total saturated fat (SFA) (g) & $27 \pm 0.6^{\mathrm{a}}$ & $27 \pm 0.7^{\mathrm{a}}$ & $25 \pm 0.8^{\mathrm{b}}$ & $25 \pm 0.7^{b}$ & $<0.0001$ \\
\hline Total trans Fat (TRANS) (g) & $5.2 \pm 0.1^{\mathrm{a}}$ & $5.3 \pm 0.1^{\mathrm{a}}$ & $5.0 \pm 0.2^{\mathrm{a}}$ & $4.4 \pm 0.2^{\mathrm{b}}$ & $<0.0001$ \\
\hline Cholesterol (mg) & $307 \pm 8^{\mathrm{a}}$ & $309 \pm 8^{\mathrm{a}}$ & $272 \pm 8^{\mathrm{b}}$ & $244 \pm 6^{\mathrm{c}}$ & $<0.0001$ \\
\hline Total carbohydrate (g) & $228 \pm 5^{\mathrm{a}}$ & $233 \pm 5^{\mathrm{a}}$ & $246 \pm 7^{\mathrm{b}}$ & $253 \pm 6^{\mathrm{b}}$ & $<0.0001$ \\
\hline Dietary fiber (g) & $16 \pm 0.4^{\mathrm{a}}$ & $16 \pm 0.4^{\mathrm{a}}$ & $18 \pm 0.5^{\mathrm{b}}$ & $19 \pm 0.5^{\mathrm{b}}$ & $<0.0001$ \\
\hline Total sugar $(g)$ & $104 \pm 4^{\mathrm{a}}$ & $104 \pm 3^{\mathrm{a}}$ & $113 \pm 4^{\mathrm{b}}$ & $117 \pm 4^{\mathrm{b}}$ & $<0.0001$ \\
\hline Added sugar (g) & $69 \pm 2^{\mathrm{a}}$ & $67 \pm 2^{\mathrm{a}}$ & $68 \pm 2^{\mathrm{a}}$ & $67 \pm 2^{\mathrm{a}}$ & 0.7652 \\
\hline Total protein $(\mathrm{g})$ & $78 \pm 1^{\mathrm{a}}$ & $78 \pm 1^{\mathrm{a}}$ & $77 \pm 2^{\mathrm{a}}$ & $80 \pm 1^{\mathrm{a}}$ & 0.2402 \\
\hline Vitamin A (mcg rae) & $735 \pm 33^{\mathrm{a}}$ & $724 \pm 30^{\mathrm{a}}$ & $805 \pm 36^{\mathrm{ab}}$ & $867 \pm 29^{b}$ & 0.0020 \\
\hline Vitamin C (mg) & $81 \pm 3^{\mathrm{a}}$ & $85 \pm 4^{\mathrm{a}}$ & $94 \pm 4^{\mathrm{ab}}$ & $99 \pm 4^{\mathrm{b}}$ & 0.0011 \\
\hline Vitamin D (mcg) & $4.2 \pm 0.2^{\mathrm{a}}$ & $4.7 \pm 0.2^{\mathrm{ab}}$ & $5.3 \pm 0.2^{\mathrm{b}}$ & $6.5 \pm 0.2^{c}$ & $<0.0001$ \\
\hline Vitamin E (mg alpha-tocopherol) & $6.5 \pm 0.2^{\mathrm{a}}$ & $6.6 \pm 0.2^{\mathrm{a}}$ & $7.3 \pm 0.3^{\mathrm{a}}$ & $7.3 \pm 0.3^{\mathrm{a}}$ & 0.0245 \\
\hline Thiamin (mg) & $1.6 \pm 0.03^{\mathrm{a}}$ & $1.7 \pm 0.03^{\mathrm{b}}$ & $1.8 \pm 0.04^{\mathrm{c}}$ & $1.9 \pm 0.04^{\mathrm{d}}$ & $<0.0001$ \\
\hline Riboflavin (mg) & $2.1 \pm 0.04^{\mathrm{a}}$ & $2.2 \pm 0.04^{\mathrm{a}}$ & $2.4 \pm 0.05^{\mathrm{b}}$ & $2.6 \pm 0.05^{\mathrm{c}}$ & $<0.0001$ \\
\hline Niacin (mg) & $21.9 \pm 0.4^{\mathrm{a}}$ & $22.5 \pm 0.4^{\mathrm{a}}$ & $23.5 \pm 0.5^{\mathrm{b}}$ & $25.8 \pm 0.5^{c}$ & $<0.0001$ \\
\hline Vitamin B6 (mg) & $1.6 \pm 0.03^{\mathrm{a}}$ & $1.7 \pm 0.03^{\mathrm{a}}$ & $1.9 \pm 0.04^{\mathrm{b}}$ & $2.3 \pm 0.06^{\mathrm{c}}$ & $<0.0001$ \\
\hline Folate $(\mathrm{mcg})$ & $437 \pm 8^{\mathrm{a}}$ & $491 \pm 9^{b}$ & $588 \pm 12^{\mathrm{c}}$ & $743 \pm 20^{\mathrm{d}}$ & $<0.0001$ \\
\hline Vitamin B12 (mg) & $5.1 \pm 0.2^{\mathrm{a}}$ & $5.3 \pm 0.2^{\mathrm{a}}$ & $5.6 \pm 0.2^{\mathrm{a}}$ & $7.0 \pm 0.2^{\mathrm{b}}$ & $<0.0001$ \\
\hline Sodium (mg) & $3509 \pm 59^{\mathrm{ab}}$ & $3584 \pm 67^{\mathrm{a}}$ & $3450 \pm 75^{\mathrm{ab}}$ & $3428 \pm 69^{b}$ & 0.0146 \\
\hline Potassium (mg) & $2544 \pm 52^{\mathrm{a}}$ & $2599 \pm 51^{a}$ & $2775 \pm 65^{\mathrm{b}}$ & $2875 \pm 61^{\mathrm{b}}$ & $<0.0001$ \\
\hline Calcium (mg) & $759 \pm 21^{\mathrm{a}}$ & $781 \pm 20^{\mathrm{a}}$ & $895 \pm 28^{\mathrm{b}}$ & $987 \pm 30^{c}$ & $<0.0001$ \\
\hline Iron (mg) & $13 \pm 0.3^{\mathrm{a}}$ & $14 \pm 0.3^{\mathrm{b}}$ & $16 \pm 0.3^{c}$ & $19 \pm 0.4^{\mathrm{d}}$ & $<0.0001$ \\
\hline Magnesium (mg) & $248 \pm 5^{\mathrm{a}}$ & $252 \pm 5^{\mathrm{a}}$ & $274 \pm 6^{\mathrm{b}}$ & $294 \pm 6^{c}$ & $<0.0001$ \\
\hline Zinc (mg) & $10.2 \pm 0.2^{\mathrm{a}}$ & $10.2 \pm 0.2^{\mathrm{ab}}$ & $10.8 \pm 0.3^{\mathrm{b}}$ & $12.3 \pm 0.3^{\mathrm{c}}$ & $<0.0001$ \\
\hline Whole grains (servings/14 d) & $5.4 \pm 6^{\mathrm{a}}$ & $6.8 \pm 5^{\mathrm{a}}$ & $8.8 \pm 6^{\mathrm{b}}$ & $13.0 \pm 8^{c}$ & $<0.0001$ \\
\hline
\end{tabular}

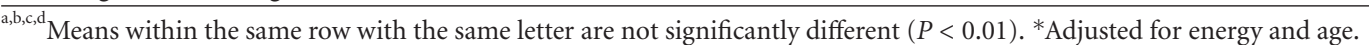

When comparing the rates of overweight and obesity across RTE cereal consumption levels in analysis adjusted for age and age ${ }^{2}$, significant differences in mean $\%$ overweight or obese were found for males but not for females (Table 5). Among men, the rate of overweight and obesity $(\mathrm{BMI} \geq 25)$ was lower among those in Q4 compared to Q1 and Q2
$(P=0.0433)$. Among men, the rate of obesity (BMI $\geq 30)$ was lower among Q4 compared to Q2. However, no significant differences were observed in other groups. For women, there were no significant differences between quartiles. Results were similar in analysis adjusted for age only (data not shown). 
TABle 3: Adjusted* mean daily nutrient intake for adult women, ages 55+, by quartile of RTE cereal consumption pattern.

\begin{tabular}{|c|c|c|c|c|c|}
\hline \multirow{4}{*}{ Nutrient } & \multicolumn{4}{|c|}{ Quartile of RTE cereal consumption } & \multirow{4}{*}{$P$} \\
\hline & Q1 & Q2 & Q3 & Q4 & \\
\hline & 0 Servings & 1-3 Servings & 4-7 Servings & $8+$ Servings & \\
\hline & Mean \pm SD & Mean \pm SD & Mean \pm SD & Mean $\pm \mathrm{SD}$ & \\
\hline Energy (kcal) & $1363 \pm 24^{\mathrm{a}}$ & $1510 \pm 28^{\mathrm{b}}$ & $1570 \pm 32^{\mathrm{b}}$ & $1622 \pm 33^{b}$ & $<0.0001$ \\
\hline Total fat (g) & $60 \pm 1.1^{\mathrm{a}}$ & $60 \pm 1.2^{\mathrm{a}}$ & $58 \pm 1.4^{\mathrm{b}}$ & $55 \pm 1.4^{\mathrm{c}}$ & $<0.0001$ \\
\hline Total saturated fat (SFA) (g) & $20.0 \pm 0.4^{\mathrm{a}}$ & $20.0 \pm 0.5^{\mathrm{a}}$ & $19.3 \pm 0.5^{\mathrm{ab}}$ & $18.7 \pm 0.5^{\mathrm{b}}$ & $<0.0001$ \\
\hline Total trans fat (TRANS) (g) & $4.0 \pm 0.1^{\mathrm{a}}$ & $4.0 \pm 0.1^{\mathrm{a}}$ & $3.7 \pm 0.1^{\mathrm{b}}$ & $3.3 \pm 0.1^{\mathrm{c}}$ & $<0.0001$ \\
\hline Cholesterol (mg) & $216 \pm 6^{\mathrm{a}}$ & $227 \pm 5^{\mathrm{a}}$ & $212 \pm 6^{\mathrm{a}}$ & $188 \pm 5^{\mathrm{b}}$ & $<0.0001$ \\
\hline Total carbohydrate (g) & $183 \pm 3^{\mathrm{a}}$ & $185 \pm 4^{\mathrm{ab}}$ & $190 \pm 4^{\mathrm{bc}}$ & $197 \pm 5^{c}$ & $<0.0001$ \\
\hline Dietary fiber (g) & $13 \pm 0.3^{\mathrm{a}}$ & $13 \pm 0.3^{\mathrm{a}}$ & $13 \pm 0.3^{\mathrm{a}}$ & $15 \pm 0.4^{\mathrm{b}}$ & $<0.0001$ \\
\hline Total sugar (g) & $88 \pm 2^{\mathrm{a}}$ & $87 \pm 3^{a}$ & $91 \pm 3^{\mathrm{a}}$ & $92 \pm 3^{\mathrm{a}}$ & 0.0654 \\
\hline Added sugar (g) & $58 \pm 1^{\mathrm{a}}$ & $56 \pm 1^{\mathrm{a}}$ & $56 \pm 2^{\mathrm{a}}$ & $53 \pm 2^{\mathrm{a}}$ & 0.1569 \\
\hline Total protein $(\mathrm{g})$ & $58 \pm 1^{\mathrm{a}}$ & $59 \pm 1^{\mathrm{a}}$ & $60 \pm 1^{\mathrm{a}}$ & $61 \pm 1^{\mathrm{a}}$ & 0.0648 \\
\hline Vitamin A (mcg rae) & $588 \pm 21^{\mathrm{a}}$ & $578 \pm 18^{\mathrm{a}}$ & $631 \pm 22^{\mathrm{ab}}$ & $679 \pm 21^{b}$ & 0.0005 \\
\hline Vitamin C (mg) & $71 \pm 3^{\mathrm{a}}$ & $68 \pm 3^{\mathrm{a}}$ & $76 \pm 3^{\mathrm{ab}}$ & $84 \pm 3^{\mathrm{b}}$ & 0.0001 \\
\hline Vitamin D (mcg) & $3.2 \pm 0.1^{\mathrm{a}}$ & $3.8 \pm 0.1^{b}$ & $4.2 \pm 0.1^{b}$ & $4.9 \pm 0.1^{\mathrm{c}}$ & $<0.0001$ \\
\hline Vitamin E (mg alpha-tocopherol) & $5.5 \pm 0.2^{\mathrm{a}}$ & $5.2 \pm 0.2^{\mathrm{a}}$ & $5.8 \pm 0.2^{\mathrm{a}}$ & $5.9 \pm 0.2^{\mathrm{a}}$ & 0.0336 \\
\hline Thiamin (mg) & $1.20 \pm 0.02^{\mathrm{a}}$ & $1.26 \pm 0.02^{\mathrm{b}}$ & $1.34 \pm 0.03^{\mathrm{c}}$ & $1.49 \pm 0.03^{\mathrm{d}}$ & $<0.0001$ \\
\hline Riboflavin (mg) & $1.5 \pm 0.03^{\mathrm{a}}$ & $1.7 \pm 0.03^{\mathrm{b}}$ & $1.8 \pm 0.04^{\mathrm{c}}$ & $2.0 \pm 0.04^{\mathrm{d}}$ & $<0.0001$ \\
\hline Niacin (mg) & $16 \pm 0.3^{\mathrm{a}}$ & $17 \pm 0.3^{\mathrm{a}}$ & $18 \pm 0.3^{\mathrm{b}}$ & $20 \pm 0.4^{\mathrm{c}}$ & $<0.0001$ \\
\hline Vitamin B6 (mg) & $1.2 \pm 0.02^{\mathrm{a}}$ & $1.3 \pm 0.02^{\mathrm{a}}$ & $1.5 \pm 0.03^{\mathrm{b}}$ & $1.8 \pm 0.05^{\mathrm{c}}$ & $<0.0001$ \\
\hline Folate (mcg) & $344 \pm 6^{\mathrm{a}}$ & $384 \pm 7^{\mathrm{b}}$ & $471 \pm 10^{c}$ & $600 \pm 16^{\mathrm{d}}$ & $<0.0001$ \\
\hline Vitamin B12 (mg) & $3.7 \pm 0.1^{\mathrm{a}}$ & $4.0 \pm 0.1^{\mathrm{ab}}$ & $4.4 \pm 0.1^{\mathrm{b}}$ & $5.7 \pm 0.2^{c}$ & $<0.0001$ \\
\hline Sodium (mg) & $2640 \pm 43^{\mathrm{a}}$ & $2697 \pm 45^{\mathrm{a}}$ & $2622 \pm 50^{\mathrm{a}}$ & $2585 \pm 51^{\mathrm{a}}$ & 0.0263 \\
\hline Potassium (mg) & $1988 \pm 34^{\mathrm{a}}$ & $2036 \pm 39^{a}$ & $2095 \pm 44^{\mathrm{a}}$ & $2246 \pm 44^{\mathrm{b}}$ & $<0.0001$ \\
\hline Calcium (mg) & $597 \pm 15^{\mathrm{a}}$ & $637 \pm 15^{\mathrm{ab}}$ & $690 \pm 17^{b}$ & $765 \pm 19^{c}$ & $<0.0001$ \\
\hline Iron $(\mathrm{mg})$ & $10 \pm 0.2^{\mathrm{a}}$ & $11 \pm 0.2^{\mathrm{a}}$ & $13 \pm 0.2^{\mathrm{b}}$ & $15 \pm 0.3^{c}$ & $<0.0001$ \\
\hline Magnesium (mg) & $198 \pm 4^{\mathrm{a}}$ & $202 \pm 4^{\mathrm{a}}$ & $207 \pm 5^{\mathrm{a}}$ & $230 \pm 5^{b}$ & $<0.0001$ \\
\hline Zinc (mg) & $7.6 \pm 0.2^{\mathrm{a}}$ & $7.6 \pm 0.1^{\mathrm{a}}$ & $8.1 \pm 0.2^{\mathrm{a}}$ & $9.3 \pm 0.2^{b}$ & $<0.0001$ \\
\hline Whole grain (servings/14 d) & $6.1 \pm 6^{\mathrm{a}}$ & $7.3 \pm 6^{\mathrm{a}}$ & $8.8 \pm 6^{\mathrm{b}}$ & $12.3 \pm 7^{\mathrm{c}}$ & $<0.0001$ \\
\hline
\end{tabular}

${ }_{\mathrm{a}, \mathrm{b}, \mathrm{c}, \mathrm{d}}$ Means within the same row with the same letter are not significantly different $(P<0.01)$. *Adjusted for energy and age.

\section{Discussion}

Study results suggest that frequent RTE cereal consumption may be associated with better nutrient intake profiles and higher whole grain intake in older Americans. Among older men RTE cereal consumption may be associated with lower BMI. Key nutrients that are typically underconsumed in older American populations include protein, fiber, vitamins B12, D, and E, calcium, magnesium, and zinc. Nutrients for which overconsumption is a concern include fat, cholesterol, vitamin A, iron, and zinc. Frequent consumption of RTE cereal was found to be associated with higher intake of all key underconsumed nutrients expect protein, which was not significantly different between the groups. In addition, consumption of whole grains for Q4 was more than double than the Q1 (nonconsuming group). RTE cereal consumption was also associated with lower energy adjusted fat and cholesterol intakes.

It was not surprising to find the positive association between higher RTE cereal consumption with higher intakes of vitamins and minerals, as many RTE cereals are fortified with vitamins and minerals and other studies have found similar associations for both children and adults $[7,14,15$, 17, 21]. In addition, RTE cereal consumption is associated with greater intake of milk and calcium, as milk and RTE cereal are usually consumed together [19].

Breakfast intake and frequent RTE cereal consumption have been associated with lower BMI based on a number of cross-sectional studies [14-17]. However, BMI is not an ideal measure of body fatness or mortality risk for older individuals and several studies suggest abdominal circumference may be a better measure of overweight and obesity in an elderly population $[13,22]$. This study has data only on BMI as no measure of waist circumference was gathered. In this study, significant associations between RTE cereal consumption and body weight were found only for men. This finding differs from Song's data for adults' $\geq 19$ years of age, which found an inverse association between RTE cereal consumption and BMI for women but not men [17].

There are a number of strengths of this study. First, while many studies have data from only 2 to 4 days of food records; 
TABLE 4: Percentage of adults 55+ falling below the Estimated Average Requirement (EAR) by RTE cereal consumption pattern.

\begin{tabular}{|c|c|c|c|c|c|c|c|c|c|c|}
\hline \multirow{3}{*}{ Nutrient } & \multicolumn{10}{|c|}{ Percent falling below EAR } \\
\hline & \multicolumn{5}{|c|}{ Men } & \multicolumn{5}{|c|}{ Women } \\
\hline & Q1 & Q2 & Q3 & Q4 & $P$ & Q1 & Q2 & Q3 & Q4 & $P$ \\
\hline Vitamin A & $58.4^{\mathrm{a}}$ & $52.7^{\mathrm{a}}$ & $35.8^{\mathrm{b}}$ & $20.5^{c}$ & $<0.0001$ & $55.2^{\mathrm{w}}$ & $44.8^{\mathrm{x}}$ & $34.9^{y}$ & $17.6^{\mathrm{z}}$ & $<0.0001$ \\
\hline Vitamin C & $58.0^{\mathrm{a}}$ & $53.1^{\mathrm{a}}$ & $38.2^{\mathrm{b}}$ & $40.0^{\mathrm{b}}$ & $<0.0001$ & $55.2^{\mathrm{w}}$ & $50.2^{\mathrm{wx}}$ & $44.2^{\mathrm{xy}}$ & $35.6^{\mathrm{y}}$ & 0.0002 \\
\hline Vitamin E & $95.2^{\mathrm{a}}$ & $96.1^{\mathrm{a}}$ & $91.5^{\mathrm{ab}}$ & $87.5^{\mathrm{b}}$ & 0.0042 & $97.3^{\mathrm{w}}$ & $97.8^{\mathrm{w}}$ & $94.4^{\mathrm{w}}$ & $95.6^{\mathrm{w}}$ & 0.1833 \\
\hline Thiamin & $14.7^{\mathrm{a}}$ & $6.3^{\mathrm{b}}$ & $1.8^{\mathrm{bc}}$ & $0.5^{\mathrm{c}}$ & $<0.0001$ & $29.3^{\mathrm{w}}$ & $15.2^{\mathrm{x}}$ & $9.3^{x y}$ & $5.4^{y}$ & $<0.0001$ \\
\hline Riboflavin & $3.9^{\mathrm{a}}$ & $1.0^{\mathrm{b}}$ & $0.0^{\mathrm{b}}$ & $0.0^{\mathrm{b}}$ & 0.0018 & $13.1^{\mathrm{w}}$ & $2.5^{\mathrm{x}}$ & $0.5^{\mathrm{x}}$ & $0.0^{\mathrm{x}}$ & $<0.0001$ \\
\hline Niacin & $3.9^{\mathrm{a}}$ & $3.9^{\mathrm{a}}$ & $2.4^{\mathrm{ab}}$ & $0.0^{\mathrm{b}}$ & 0.1547 & $14.3^{\mathrm{w}}$ & $8.7^{\mathrm{x}}$ & $4.7^{x y}$ & $2.0^{z}$ & $<0.0001$ \\
\hline Vitamin B6 & $40.7^{\mathrm{a}}$ & $30.4^{\mathrm{b}}$ & $11.5^{\mathrm{c}}$ & $3.5^{\mathrm{d}}$ & $<0.0001$ & $68.0^{\mathrm{w}}$ & $54.5^{x}$ & $32.6^{y}$ & $13.2^{\mathrm{z}}$ & $<0.0001$ \\
\hline Folate & $26.4^{\mathrm{a}}$ & $9.2^{\mathrm{b}}$ & $1.8^{\mathrm{c}}$ & $1.0^{\mathrm{c}}$ & $<0.0001$ & $54.1^{\mathrm{w}}$ & $28.9^{x}$ & $11.6^{y}$ & $3.9^{\mathrm{z}}$ & $<0.0001$ \\
\hline Vitamin B12 & $6.9^{\mathrm{a}}$ & $1.5^{\mathrm{b}}$ & $0.6^{\mathrm{b}}$ & $0.0^{\mathrm{b}}$ & $<0.0001$ & $19.7^{\mathrm{w}}$ & $7.2^{\mathrm{x}}$ & $3.7^{x y}$ & $1.0^{y}$ & $<0.0001$ \\
\hline Iron & $1.7^{\mathrm{a}}$ & $1.5^{\mathrm{a}}$ & $0.0^{\mathrm{a}}$ & $0.0^{\mathrm{a}}$ & 0.1161 & $3.1^{\mathrm{w}}$ & $0.7^{\mathrm{x}}$ & $0.0^{\mathrm{x}}$ & $0.0^{\mathrm{x}}$ & 0.0025 \\
\hline Magnesium & $90.9^{a}$ & $89.9^{a}$ & $82.4^{\mathrm{b}}$ & $69.5^{c}$ & $<0.0001$ & $91.5^{\mathrm{w}}$ & $82.0^{\mathrm{x}}$ & $79.5^{\mathrm{x}}$ & $67.8^{y}$ & $<0.0001$ \\
\hline Zinc & $52.8^{\mathrm{a}}$ & $45.9^{\mathrm{a}}$ & $32.1^{\mathrm{b}}$ & $15.5^{\mathrm{c}}$ & $<0.0001$ & $50.6^{\mathrm{w}}$ & $38.3^{\mathrm{x}}$ & $25.1^{\mathrm{y}}$ & $13.7^{\mathrm{z}}$ & $<0.0001$ \\
\hline Calcium & $74.0^{\mathrm{a}}$ & $67.2^{\mathrm{a}}$ & $49.7^{\mathrm{b}}$ & $34.0^{c}$ & $<0.0001$ & $95.8^{\mathrm{w}}$ & $89.5^{\mathrm{x}}$ & $88.4^{\mathrm{x}}$ & $77.1^{y}$ & $<0.0001$ \\
\hline Vitamin D & $95.7^{\mathrm{a}}$ & $95.7^{\mathrm{a}}$ & $95.2^{\mathrm{ab}}$ & $87.0^{\mathrm{b}}$ & 0.0010 & 99.2 & 98.9 & 98.6 & 99.0 & 0.9305 \\
\hline
\end{tabular}

${ }_{\text {abcd }}$ Proportions within the same row with same letters are not significantly different $(P<0.01)$ (men).

${ }^{\text {wxyz }}$ Proportions within the same row with same letters are not significantly different $(P<0.01)$ (women).

TABLE 5: Adjusted* mean body mass index for adults 55+ years and percent overweight or obese by quartile of cereal consumption (BMI $\geq$ 25) by RTE cereal consumption pattern (energy excluded).

\begin{tabular}{|c|c|c|c|c|c|c|}
\hline & \multicolumn{6}{|c|}{ Quartile of RTE cereal consumption } \\
\hline & & Q1 & Q2 & Q3 & Q4 & \\
\hline & & 0 Servings & 1-3 Servings & 4-7 Servings & $8+$ Servings & \\
\hline Gender/age & Sample size & \multicolumn{4}{|c|}{ Mean BMI } & Overall $P$ \\
\hline Male ages $55+$ & 803 & $28.19^{\mathrm{a}}$ & $27.96^{\mathrm{a}}$ & $27.36^{\mathrm{ab}}$ & $26.93^{b}$ & 0.0332 \\
\hline \multirow[t]{2}{*}{ Female ages $55+$} & 956 & $27.48^{\text {ba }}$ & $28.22^{\text {ba }}$ & $28.53^{\mathrm{a}}$ & $27.09^{\mathrm{b}}$ & 0.0607 \\
\hline & & \multicolumn{4}{|c|}{ Percent overweight/obese } & $P$ \\
\hline Male ages $55+$ & 803 & $74.43^{\mathrm{a}}$ & $70.69^{a}$ & $63.05^{\mathrm{b}}$ & $64.35^{\mathrm{b}}$ & 0.0433 \\
\hline \multirow[t]{2}{*}{ Female ages $55+$} & 956 & $61.11^{\mathrm{a}}$ & $63.40^{\mathrm{a}}$ & $62.57^{\mathrm{a}}$ & $58.81^{\mathrm{a}}$ & 0.7575 \\
\hline & \multicolumn{6}{|c|}{ Percent obese } \\
\hline Male ages $55+$ & 803 & $28.70^{\mathrm{ab}}$ & $30.61^{\mathrm{a}}$ & $24.42^{\mathrm{ab}}$ & $21.02^{\mathrm{b}}$ & 0.1111 \\
\hline Female ages $55+$ & 956 & $28.63^{\mathrm{a}}$ & $33.19^{\mathrm{a}}$ & $32.46^{\mathrm{a}}$ & $28.84^{\mathrm{a}}$ & 0.5622 \\
\hline
\end{tabular}

a, $V$ alues within the same row with the same letter are not significantly different $(P<0.05)$.

*Mean values adjusted for age, age ${ }^{2}$.

this study is based on 14 days of data. Measurement error due to within person coefficient of variation in food and nutrient intake is reduced in this study due to the collection of 14 days of dietary intake information. This study included a representative sample of an older US population. The sample size allowed for examining the association of RTE cereal consumption with nutrient intake and weight status in older adults, with analysis conducted separately for males and females. In addition, the nutrient and food group database NDSR is one of the most comprehensive databases available for diet research, including nutrients of interest such as vitamin $\mathrm{D}$ and few missing nutrient values.

One limitation of this study is that a number of factors that could potentially confound the association of RTE cereal with BMI were not assessed and therefore could not be adjusted for in the analysis. For example, it did not include any measure of physical activity or ability to perform daily activities. Therefore, we do not know if this consumption pattern was associated with other lifestyle patterns, such as higher levels of physical activity. Another limitation is that BMI is based on self-reported measures of height and weight, and this is not the most reliable measure since people tend to overestimate their height and underestimate weight. Another limitation is the lack of reported portion size data. Reporting of portion size is one of the most error prone areas of dietary assessment. Portion size values were imputed from NHANES data where respondents are trained and use a variety of estimation tools however; reporting error is a potential issue. Finally, data on intake of dietary nutrient supplements was not gathered. Consequently, the association of RTE cereal consumption with nutrient intake could not be examined in the context of vitamin and mineral intake 
for all sources. It is unknown if supplementation may help bridge the gap between usual nutrient intakes and dietary recommendations. RTE cereals are generally fortified and can contribute a significant proportion of nutrients to those who consume them.

Overconsumption of certain vitamins and minerals such as vitamin $\mathrm{A}$, iron, and zinc can be a risk for older Americans who eat fortified products and use vitamin and mineral supplements [23]. A recent study found $37 \%$ of men and $47 \%$ of women age $\geq 51$ years consume at least one vitamin or mineral supplement each day [23]. Data from the 1999-2000 NHANES found $63 \%$ of individuals $\geq 60$ years in age consume some type of daily dietary supplements [24]. Many older Americans may be unaware of the risk of overconsumption of vitamins and minerals and more education about this concern is needed. In addition, food manufacturers need to consider this concern for the elderly population when deciding on how to fortify RTE cereal products.

The food grouping estimates in the NDSR database are not ideal of determining whole grain intake. Food items that were grouped as "some whole grain" were not included in this study due to the uncertainty of the amount of whole grain in the food. Foods grouped as "whole grain" were counted as all whole grain, when the food may have other ingredients and also may include some refined grains. The finding of higher levels of whole grain in the highest quartile of RTE cereal consumption makes sense considering the higher intake of fiber for this group and since RTE cereal is an important contributor of whole grain in the US diet.

\section{Conclusion}

Results suggest that ready-to-eat breakfast cereals may contribute to the nutritional quality of the diets of older Americans. Prospective studies and experimental trials are needed to better evaluate the role of RTE cereal consumption in energy balance.

\section{Authors' Contribution}

A. M. Albertson and N. Joshi contributed to research design. A. C. Wold wrote the introduction and discussion for the paper. A. M. Albertson wrote the methods and results for the paper. N. Joshi did the data analysis. All authors read and approved the final paper.

\section{Acknowledgment}

The authors acknowledge Arohi Bapna for helping in editing the paper.

\section{References}

[1] US Department of Health and Human Services, Administration on Aging, Aging Statistics Census Data \& Population Estimates, http://www.aoa.gov/AoARoot/Aging_Statistics/future growth/future_growth.aspx.
[2] J. R. Sharkey, L. G. Branch, N. Zohoori, C. Giuliani, J. BusbyWhitehead, and P. S. Haines, "Inadequate nutrient intakes among homebound elderly and their correlation with individual characteristics and health-related factors," American Journal of Clinical Nutrition, vol. 76, no. 6, pp. 1435-1445, 2002.

[3] B. E. Millen, J. C. Ohls, M. Ponza, and A. C. McCool, "The Elderly Nutrition Program: an effective national framework for preventive nutrition interventions," Journal of the American Dietetic Association, vol. 102, no. 2, pp. 234-240, 2002.

[4] S. Park, M. A. Johnson, and J. G. Fischer, "Vitamin and mineral supplements: barriers and challenges for older adults," Journal of Nutrition for the Elderly, vol. 27, no. 3-4, pp. 297317, 2008.

[5] J. M. Kerver, E. J. Yang, S. Obayashi, L. Bianchi, and W. O. Song, "Meal and snack patterns are associated with dietary intake of energy and nutrients in US adults," Journal of the American Dietetic Association, vol. 106, no. 1, pp. 46-53, 2006.

[6] E. A. Gollub and D. O. Weddle, "Improvements in nutritional intake and quality of life among frail homebound older adults receiving home-delivered breakfast and lunch," Journal of the American Dietetic Association, vol. 104, no. 8, pp. 1227-1235, 2004.

[7] M. A. Galvin, M. Kiely, and A. Flynn, "Impact of ready-toeat breakfast cereal (RTEBC) consumption on adequacy of micronutrient intakes and compliance with dietary recommendations in Irish adults," Public Health Nutrition, vol. 6, no. 4, pp. 351-363, 2003.

[8] K. J. Morgan and M. E. Zabik, "The influence of ready-toeat cereal consumption at breakfast on nutrient intakes of individuals 62 years and older," Journal of the American College of Nutrition, vol. 3, no. 1, pp. 27-44, 1984.

[9] J. L. Bachman, J. Reedy, A. F. Subar, and S. M. Krebs-Smith, "Sources of food group intakes among the US population, 2001-2002," Journal of the American Dietetic Association, vol. 108, no. 5, pp. 804-814, 2008.

[10] N. M. McKeown, M. Yoshida, M. K. Shea et al., "Whole-grain intake and cereal fiber are associated with lower abdominal adiposity in older adults," Journal of Nutrition, vol. 139, no. 10, pp. 1950-1955, 2009.

[11] D. K. Houston, B. J. Nicklas, and C. A. Zizza, "Weighty concerns: the growing prevalence of obesity among older adults," Journal of the American Dietetic Association, vol. 109, no. 11, pp. 1886-1895, 2009.

[12] K. M. Flegal, D. Carroll, B. K. Kit, and C. L. Ogden, "Prevalence of obesity and trends in the distribution of body mass index among US adults, 1999-2010," Journal of the American Medical Association, vol. 307, no. 5, pp. 491-497, 2012.

[13] J. C. Seidell and T. L. S. Visscher, "Body weight and weight change and their health implications for the elderly," European Journal of Clinical Nutrition, vol. 54, supplement 3, pp. S33S39, 2000.

[14] A. M. Albertson, G. H. Anderson, S. J. Crockett, and M. T. Goebel, "Ready-to-eat cereal consumption: its relationship with BMI and nutrient intake of children aged 4 to 12 years," Journal of the American Dietetic Association, vol. 103, no. 12, pp. 1613-1619, 2003.

[15] A. M. Albertson, S. G. Affenito, R. Bauserman, N. M. Holschuh, A. L. Eldridge, and B. A. Barton, "The relationship of ready-to-eat cereal consumption to nutrient intake, blood lipids, and body mass index of children as they age through adolescence," Journal of the American Dietetic Association, vol. 109, no. 9, pp. 1557-1565, 2009. 
[16] S. Cho, M. Dietrich, C. J. P. Brown, C. A. Clark, and G. Block, "The effect of breakfast type on total daily energy intake and body mass index: results from the Third National Health and Nutrition Examination Survey (NHANES III)," Journal of the American College of Nutrition, vol. 22, no. 4, pp. 296-302, 2003.

[17] W. O. Song, O. K. Chun, S. Obayashi, S. Cho, and C. E. Chung, "Is consumption of breakfast associated with body mass index in US adults?" Journal of the American Dietetic Association, vol. 105, no. 9, pp. 1373-1382, 2005.

[18] L. R. Purslow, M. S. Sandhu, N. Forouhi et al., "Energy intake at breakfast and weight change: prospective study of 6,764 middle-aged men and women," American Journal of Epidemiology, vol. 167, no. 2, pp. 188-192, 2008.

[19] W. O. Song, O. K. Chun, J. Kerver, S. Cho, C. E. Chung, and S. J. Chung, "Ready-to-eat breakfast cereal consumption enhances milk and calcium intake in the US population," Journal of the American Dietetic Association, vol. 106, no. 11, pp. 1783-1789, 2006.

[20] The NPD Group, National Eating Trends, 2007-2008.

[21] B. A. Barton, A. L. Eldridge, D. Thompson et al., "The relationship of breakfast and cereal consumption to nutrient intake and body mass index: the National Heart, Lung, and Blood Institute Growth and Health Study," Journal of the American Dietetic Association, vol. 105, no. 9, pp. 1383-1389, 2005.

[22] T. L. S. Visscher, J. C. Seidell, A. Molarius, D. Van Der Kuip, A. Hofman, and J. C. M. Witteman, "A comparison of body mass index, waist-hip ratio and waist circumference as predictors of all-cause mortality among the elderly: the Rotterdam study," International Journal of Obesity, vol. 25, no. 11, pp. 1730-1735, 2001.

[23] R. S. Sebastian, L. E. Cleveland, J. D. Goldman, and A. J. Moshfegh, "Older adults who use vitamin/mineral supplements differ from nonusers in nutrient intake adequacy and dietary attitudes," Journal of the American Dietetic Association, vol. 107, no. 8, pp. 1322-1332, 2007.

[24] K. Radimer, B. Bindewald, J. Hughes, B. Ervin, C. Swanson, and M. F. Picciano, "Dietary supplement use by US adults: data from the National Health and Nutrition Examination Survey, 1999-2000," American Journal of Epidemiology, vol. 160, no. 4, pp. 339-349, 2004. 


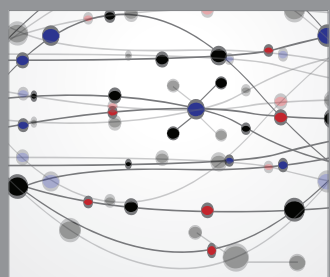

The Scientific World Journal
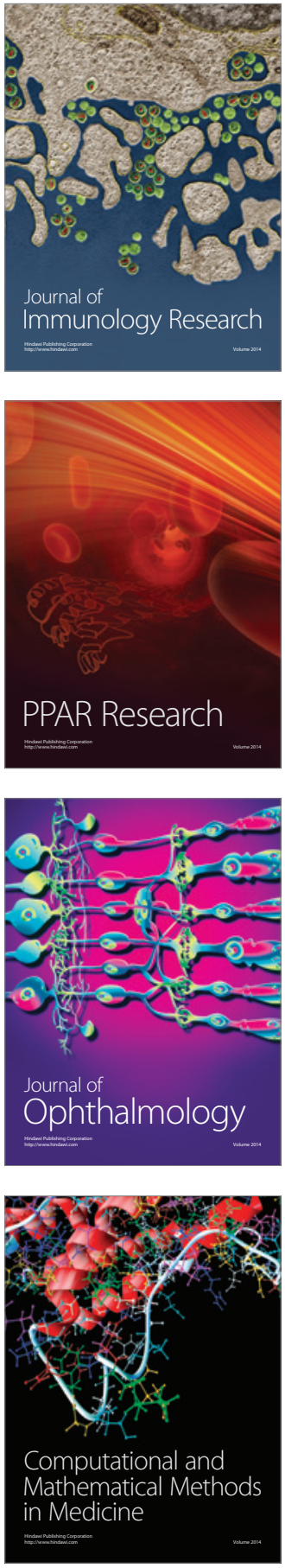

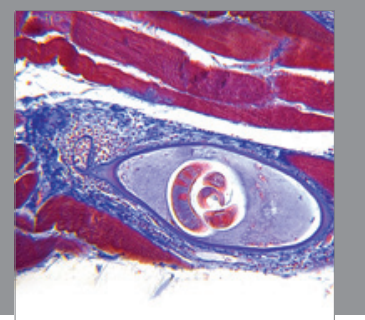

Gastroenterology

Research and Practice
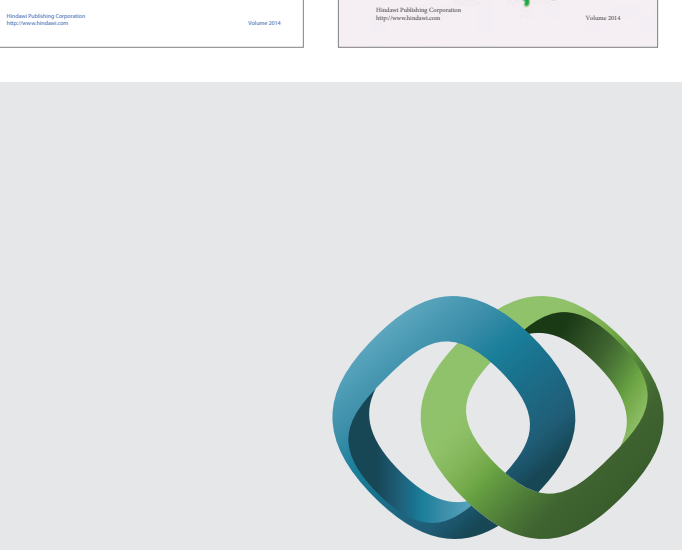

\section{Hindawi}

Submit your manuscripts at

http://www.hindawi.com
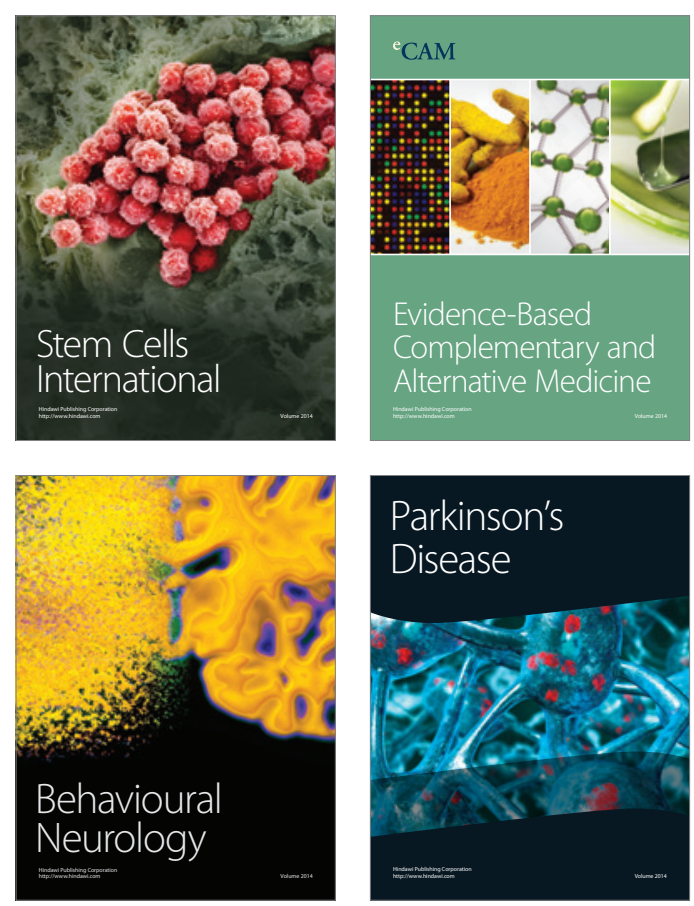

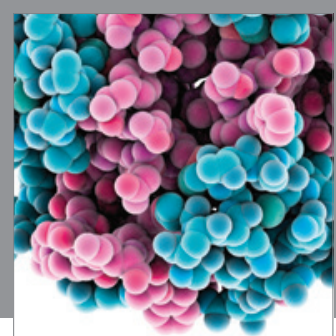

Journal of
Diabetes Research

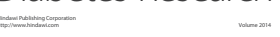

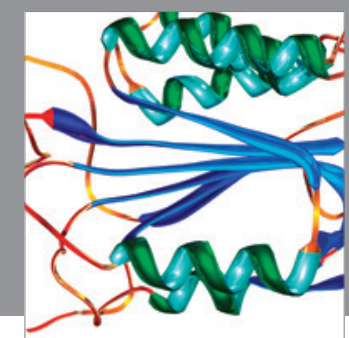

Disease Markers
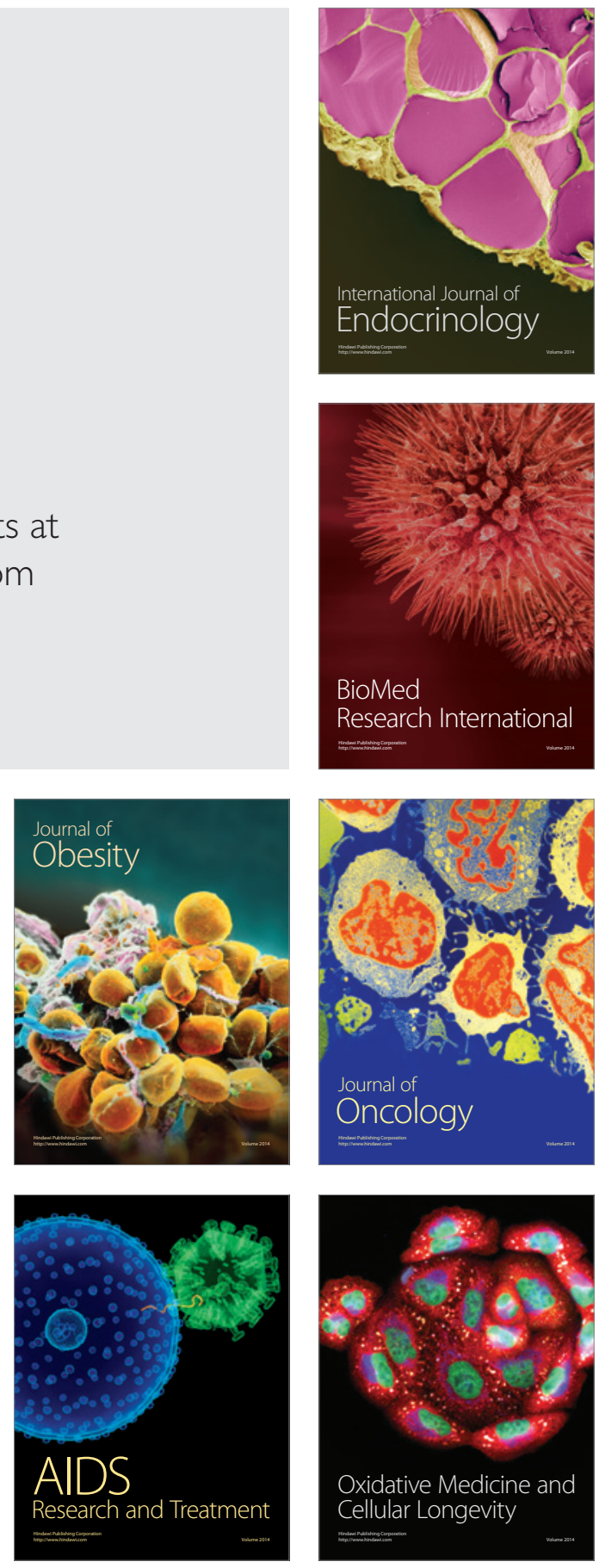